\title{
O pluralismo religioso no horizonte de um ecumenismo planetário em Claude Geffré
}

\section{Religious pluralism on the horizon of a planetary ecumenism in Claude Geffré}

\section{Tiago de Fraga Gomes*}

\section{RESUMO}

Segundo Claude Geffré, Pentecostes é a imagem bíblica neotestamentária que afirma a manifestação pluriforme do desígnio de Deus, em contraposição à imagem bíblica veterotestamentária de Babel, expressão da idolatria monolítica de uma humanidade que se coloca no lugar de Deus. O fenômeno da religião em sua expressão plural é uma questão intransponível para a razão teológica contemporânea. Partindo das obras Crer e interpretar e De Babel a Pentecostes de Geffré, e em diálogo com autores correlacionados, o presente texto pretende refletir sobre a necessidade de um diálogo entre as religiões no contexto de uma sociedade globalizada. A construção de um ecumenismo planetário e de um ethos mundial depende disso. É preciso superar toda forma de fundamentalismo escriturístico e de integrismo doutrinal que são atitudes perniciosas para a convivência humana sadia a nível planetário.

PALAVRAS-CHAVE: Ecumenismo planetário. Fundamentalismo. Integrismo. Pluralismo. Claude Geffré.

\section{ABSTRACT}

According to Claude Geffré, Pentecost is the biblical New Testament image that affirms the pluriform manifestation of God's design, in contrast to the Old Testament biblical image of Babel, an expression of the monolithic idolatry of a humanity that stands in God's place. The phenomenon of religion in its plural expression is an insurmountable issue for contemporary theological reason. Starting from the works Believing and interpreting and from Babel to Pentecostes of Geffré, and in dialogue with related authors, the present text intends to reflect on the necessity of a dialogue between the religions in the context of a globalized society. The construction of a planetary ecumenism and a world ethos depends on this. It's necessary to overcome all forms of Scriptural fundamentalism and doctrinal integrism which are pernicious attitudes towards healthy human coexistence at planetary level.

KEYWORDS: Planetary ecumenism. Fundamentalism. Integrism. Pluralism. Claude Geffré. 


\section{INTRODUÇÃO}

A experiência histórica e social atual concilia ao mesmo tempo secularização, ateísmo, indiferença religiosa e retorno do sagrado em sua manifestação multiforme. $\mathrm{O}$ diálogo ecumênico e inter-religioso quebrou o modelo absolutista católico que vigorou praticamente até a metade do século XX. A consciência histórica atual de um pluralismo religioso instransponível convida a reinterpretar a unicidade do cristianismo como religião de salvação entre as diversas religiões do mundo. ${ }^{1}$ Por muito tempo prevaleceu a ideia de que o cristianismo progressivamente triunfaria sobre as outras religiões, na medida em que essas eram a expressão da ignorância, da superstição ou da idolatria. A partir da experiência do fracasso da missão cristã, enquanto universalização de fato, e da vitalidade das religiões não cristãs, impõe-se a questão teológica se um pluralismo religioso se deve simplesmente à cegueira e ao pecado humano, ou se realmente corresponde a um desígnio misterioso de Deus.

A questão do pluralismo religioso está no centro do pensamento de Claude Geffré. Segundo Geffré, "uma teologia responsável é uma teologia que leva em conta as dimensões históricas novas da inteligência da fé. Hoje, no início do século XXI, a teologia tem de enfrentar um novo desafio, o do pluralismo religioso." ${ }_{2}$ Nesse sentido, a teologia cristã precisa ser capaz de dialogar criativamente com o pensamento teológico das outras religiões. Parafraseando a fala do Papa Francisco na Evangelii Gaudium n. 14, o cristianismo não deve crescer por proselitismo, mas por atração, ou seja, pelo testemunho de unidade, de fraternidade e de paz.

A partir de uma postura hermenêutica, Geffré enfatiza o caráter radicalmente histórico da teologia cristã, justamente "em função do devir da razão humana e em função da experiência da Igreja como eco dos novos estados de consciência do mundo." ${ }^{3}$ A teologia hermenêutica não toma como ponto de partida "um conjunto de proposições imutáveis de fé, mas a pluralidade de escrituras compreendidas dentro do campo hermenêutico aberto pelo evento Jesus Cristo"4, relevando o papel essencial da historicidade para reinterpretar a experiência cristã fundamental, relacionando-a com a experiência histórica das pessoas de hoje. "A missão da teologia como hermenêutica é atualizar e tornar pertinente para a contemporaneidade a mensagem da revelação." ${ }^{5} \mathrm{~A}$ questão do pluralismo religioso põe em xeque uma compreensão fechada e absolutista da identidade e da soteriologia cristã, e propõe uma nova interpretação para a pretensão cristã à unicidade e à universalidade.

Em um mundo globalizado, a experiência da pluralidade das tradições religiosas coincide com a consciência cada vez mais clara da relatividade da religião cristã, além do fato de que em uma sociedade pós-moderna, há a passagem de um saber absoluto para um testemunho hermenêutico. O cristianismo já não pode se considerar como a única religião verdadeira que detém a totalidade dos meios salvíficos. A evolução do pensamento teológico leva necessariamente a buscar fundamentar as razões de um pluralismo religioso, não apenas de fato, mas de princípio ${ }^{6}$, que forneça o fundamento teológico para o diálogo inter-religioso. Nesse diálogo, é importante ressaltar a singularidade e a importância específica de cada religião diante do misterioso desígnio

\footnotetext{
${ }^{1}$ Cf. GEFFRÉ, Claude. Crer e interpretar, p. 134.

${ }^{2}$ GEFFRÉ, Claude. De Babel à Pentecostes, p. 27.

${ }^{3}$ GEFFRÉ, Claude. De Babel à Pentecostes, p. 5.

${ }^{4}$ GEFFRÉ, Claude. Como fazer teologia hoje, p. 68.

${ }_{5}^{5}$ GOMES, Tiago de Fraga. Hermenêutica teológica e teologia da revelação em Claude Geffré, p. 54.

${ }^{6}$ Cf. DUPUIS, Jacques. Rumo a uma teologia cristã do pluralismo religioso, p. 526.
} 
divino, revelado na economia histórica, empreendendo assim uma humilde busca compartilhada da verdade.

O período pós-conciliar na teologia católica, foi capaz de estabelecer um equilíbrio entre um cristocentrismo constitutivo salvífico universal e um pluralismo inclusivo, que reconhece os valores salutares propagados pelas outras religiões. Nesse sentido, Geffré afirma "que é possível conciliar a universalidade do mistério de Cristo para a salvação com um verdadeiro pluralismo inclusivo" ", e colocar como fundamento teológico para o mesmo, o fato de que "a economia do Verbo encarnado é o sacramento de uma economia mais vasta que coincide com a história religiosa da humanidade." ${ }^{8}$ Segundo Geffré, a história humana é, desde o início, fecundada pelas sementes do Verbo e pelos dons do Espírito Santo.

A legitimidade de uma teologia do pluralismo religioso, para Geffré, está na sua abertura a se interrogar a respeito do significado das diferentes possibilidades de acesso ao desígnio criador e salvador de Deus, ultrapassando uma simples teologia do cumprimento ou acabamento, para construir uma teologia cristã das religiões, na firme convicção de que a inteligência possível a respeito do mistério de Deus pode ser enriquecida pelo testemunho das diversas tradições religiosas da humanidade. Segundo Faustino Teixeira, o campo de estudos da teologia das religiões constitui "um fenômeno típico da modernidade plural", para cuja emergência contribuiu uma série de fatores, tais como a inédita relação de proximidade entre o cristianismo e as outras religiões, favorecida pelo recente avanço das tecnologias da comunicação e, dentre outras coisas, a nova sensibilidade em face aos valores espirituais e humanos das outras tradições religiosas.

\section{PENTECOSTES COMO MANIFESTAÇÃO DA PLURALIDADE E DA ALTERIDADE IRREDUTÍVEL}

Segundo Geffré, o episódio de Babel ( Gn 11) como edificação humana, orgulhosa e prepotente, da torre única, rival da unicidade divina, retrata a tentativa de realizar uma falsa concepção de universalidade através da conquista e da hegemonia, originada da ambição idolátrica e desmedida de um desejo monolítico que intenciona usurpar o lugar de Deus. A tentação de Babel é homogeneizar. Em Pentecostes, os diferentes discursos não degradam a realidade, mas a explanam melhor. O Deus bíblico abençoa a multiplicidade. Criou a biodiversidade da natureza e dos seres, e colocou no coração humano uma sabedoria criativa, cuja expressão manifesta a pluriforme realidade da vida. A questão filosófica de fundo é a questão do uno e do múltiplo. "Com a efusão do Espírito do Ressuscitado, em Pentecostes, é permitido pensar que a pluralidade das línguas e das culturas é necessária para traduzir a riqueza multiforme do mistério de Deus" ${ }^{10}$, sendo a pluralidade das religiões um contributo importante para uma manifestação mais perfeita do mesmo.

O critério a partir do qual se deve interpretar o pluralismo das tradições religiosas é evidentemente a afirmação fundamental da vontade de salvação universal de Deus que se estende a todos os humanos desde a origem. A este respeito sempre é citado o capítulo 2 da Primeira Epístola a Timóteo: "Deus quer que todos os homens se salvem e cheguem ao conhecimento da verdade" (4-6). [...]

\footnotetext{
${ }^{7}$ GEFFRÉ, Claude. De Babel à Pentecostes, p. 8.

${ }^{8}$ GEFFRÉ, Claude. De Babel à Pentecostes, p. 54.

9 TEIXEIRA, Faustino. Teologia das religióes, p. 11.

${ }^{10}$ GEFFRÉ, Claude. De Babel à Pentecostes, p. 67.
} 
O pluralismo religioso pode pois ser considerado como um destino histórico permitido por Deus. [...] Não é proibido pensar que Pentecostes corresponde a Babel. Ora, Pentecostes é precisamente uma espécie de legitimação que é dada à pluralidade, na medida em que a riqueza superabundante do mistério de Deus não pode ser expressa a não ser por uma pluralidade de formas religiosas. ${ }^{11}$

A reminiscência da pluralidade em Pentecostes (At 2), remete a um ser humano criado plural, como homem e mulher, imagem e semelhança de Deus (imago Dei), com uma identidade e uma vocação comunial e comunitária, para viver a unidade na diversidade (imago Trinitas), como povo eleito e santificado, renovado e sustentado pela misericórdia e pela fidelidade divina, apesar das constantes fragilidades humanas emergentes no peregrinar histórico. O ser humano é um ser radicalmente plural e comunitário. Pensar a identidade e as relações humanas desde o desejo ilusório e prepotente de unicidade absoluta consiste em anular a diversidade e a multiplicidade que são obras de Deus.

Guarda-se sempre, do episódio da Torre de Babel, a confusão das línguas como castigo de Deus. Mas, de fato, o que Deus contesta é o projeto de uma língua única simbolizada por uma torre única. E o desejo nostálgico permanente de todos os fundamentalistas [...] é o de substituir a Torre por um Livro cujo mínimo traço teria o acabamento e o definitivo de uma obra imediata de Deus. O Deus criador, da Bíblia, abençoa, ao contrário, a multiplicidade. ${ }^{12}$

Babel quer ostentar a transcendência a partir da imanência de um poder centralizador. Já o evento de Pentecostes, recoloca a iniciativa divina como um dom que precisa ser acolhido e cultivado pela humanidade, com humildade sincera e docilidade livre. Diferente de Babel, em Pentecostes há um horizonte de expectativa cada vez mais amplo, constituindo um "universalismo cada vez mais explícito"13, o qual se concretiza em uma economia histórico-salvífica diversificada, conforme dito: "Nós os ouvimos anunciar em nossas próprias línguas as maravilhas de Deus!” (At 2,11). Em Babel, a uniformidade se torna confusa (do hebraico balal) pelo fechamento de uma perspectiva autocentrada. Já Pentecostes, como manifestação de uma alteridade irredutível, é o símbolo de um diálogo que preserva a especificidade de cada língua e de cada cultura. Pentecostes leva ao entendimento pela abertura à cosmovisão do outro. $\mathrm{O}$ impulso do Espírito Santo faz ir ao encontro do outro, respeitando as diferenças identitárias. Pentecostes é, nesse sentido, a fonte da comunhão na pluralidade.

Para as comunidades cristãs hodiernas, a atualização do evento de Pentecostes através da celebração da fé, ajuda a viver a esperança escatológica do Reinado de Deus cuja expectativa é que Cristo seja "tudo em todos" ( $C l 3,11)$. A forte convicção de que Deus continua a agir hoje como agiu nos primórdios do cristianismo, serve como critério para a percepção de que os feitos de Pentecostes visam à edificação da comunhão com Deus e com o próximo, na diversidade dos carismas espirituais, os quais sempre devem estar disponíveis para o bem comum, como dom de Deus para a edificação humana individual e comunitária. No entanto, algumas atitudes contraditórias surgem dessa experiência, dentre elas o fundamentalismo e o integrismo, que obstaculizam a abertura à renovação teológica e ao diálogo.

\footnotetext{
${ }^{11}$ GEFFRÉ, Claude. Crer e interpretar, p. 136-138.

${ }^{12}$ GEFFRÉ, Claude. De Babel à Pentecostes, p. 198.

${ }^{13}$ GEFFRÉ, Claude. De Babel à Pentecostes, p. 69.
} 


\section{O NEOFUNDAMENTALISMO NO CONTRAPONTO DA RENOVAÇÃO TEOLÓGICA}

Basicamente, o fundamentalismo nasce do conflito entre a fé cristã tradicional e a modernidade ilustrada e crítica. No contato com os textos sagrados, duas atitudes reducionistas, geralmente advindas de movimentos pentecostais mais radicais que anseiam por uma experiência imediata de plenitude psicológica, ameaçam a integralidade do trabalho teológico através de duas formas de instrumentalização da religião: o fundamentalismo literalista e o integrismo doutrinal.

Segundo Cássio da Silva, a atitude fundamentalista pode ser caracterizada como a "busca de valores e verdades simples, coerentes, unitárias, imutáveis, universalmente válidas e que excluem os pontos de vista discordantes." ${ }_{14} \mathrm{O}$ fundamentalismo consiste em assumir algo como fonte única e infalível da verdade e "tem suas raízes no século XVIII, como reação ao Iluminismo e à exploração científica do universo. Os estudos científicos começaram a questionar a veracidade literal dos dados bíblicos." 15 A leitura crítica da Sagrada Escritura revelou, entre outras coisas, as incoerências e as contradições no complexo processo de formação dos textos bíblicos.

No fundo, os fundamentalistas rejeitam uma leitura crítica da Sagrada Escritura, apelando para a segurança da absolutização da verdade literal, maximizando o paradigma da inerrância. Segundo Leonardo Boff, o fundamentalismo não é uma doutrina, mas pode ser compreendido como "uma forma de interpretar e viver a doutrina. É assumir a letra das doutrinas e normas sem cuidar de seu espírito e de sua inserção no processo sempre cambiante da história, que obriga a contínuas interpretações e atualizações." ${ }_{16} \mathrm{O}$ fundamentalismo absolutiza aquilo que é relativo por medo do relativismo, porém, acaba por descuidar-se da essência da verdade a qual se expressa na relatividade histórica.

Já o integrismo doutrinal sacraliza a tradição textual dogmática da Igreja sob a roupagem de uma fidelidade escrupulosa, recusando a hierarquia das verdades proposta pelo Concílio Vaticano II ( $U R$ 11), pondo no mesmo plano de importância todos os ensinamentos eclesiásticos, numa busca obstinada por um fundamento seguro. A hierarquia das verdades consiste na comparação das doutrinas católicas, percebendo que entre elas existe uma ordem ou hierarquia a partir de um nexo diverso com o fundamento da fé cristã. Esse é um princípio hermenêutico de grande fecundidade teológica que permite ordenar o intellectus fidei a partir de sua centralidade trinitária e cristológica, ou mesmo o que diz respeito àquelas "verdades necessárias à salvação" contidas na Escritura e na Tradição, distinguindo-as das verdades secundárias. ${ }^{17}$

No contexto atual, a hermenêutica representa a alternativa necessária à superação do abismo entre o fundamentalismo e integrismo, de um lado, e o relativismo e indiferentismo de outro. De fato, vistos em sua natureza íntima, fundamentalismo e relativismo são extremismos que se tocam e se eximem de sua responsabilidade textual. De um lado, encontra-se o fundamentalismo, em sua convicção e certeza da redução de significado de um texto à sua capacidade de leitura do mesmo; de outro, tem-se o relativismo, que ignora o texto, na convicção de seu vazio. ${ }^{18}$

\footnotetext{
${ }^{14}$ SILVA, Cássio Murilo Dias da. Crítica bíblica, p. 39.

${ }^{15}$ SILVA, Cássio Murilo Dias da. Crítica bíblica, p. 40.

${ }^{16}$ BOFF, Leonardo. Fundamentalismo, p. 25.

${ }^{17}$ Cf. LACOSTE, Jean-Yves. Dicionário crítico de teologia, p. 827-828.

${ }^{18}$ HAMMES, Érico João. Hermenêutica e teologia, p. 59.
} 
Geffré trata tanto do fundamentalismo escriturístico, o qual rejeita os resultados da exegese crítica, quanto do integrismo doutrinário, como fidelidade escrupulosa ao ensinamento eclesial. Para Geffré, os resultados da crítica histórica "não são uma ameaça à fé, mas antes são libertadores." ${ }^{19}$ A Escritura como testemunho é uma interpretação de fé, sob a dinâmica do Espírito Santo, com uma meta teológica. O integrismo doutrinal sacraliza a tradição dogmática da Igreja, pondo no mesmo plano de importância todos os ensinamentos, recusando a hierarquia das verdades. Segundo Geffré, os fundamentalistas realizam uma "busca obstinada de um fundamento seguro." ${ }^{20}$ Para sanar uma insegurança psicológica, o fundamentalista realiza um suicídio da inteligência.

Nesse sentido, Geffré frisa que ambas, a Escritura e a Tradição, testemunham a Palavra de Deus em sua plenitude escatológica, e, sendo assim, as atitudes fechadas e unilaterais do fundamentalismo e do integrismo não são o meio mais adequado como aproximação da verdade. É preciso ir ao encontro da verdade por aproximações sucessivas, buscando discernir a mensagem cristã fundamental expressa pelos signos linguísticos e culturais ${ }^{21}$, ou seja, trilhando a via modesta e realista da interpretação humilde e do diálogo sincero, em vista do bem comum. Do contrário, o orgulho acaba por cegar e obstinar o coração humano pelo caminho da divisão e da violência.

\section{O DIÁLOGO ENTRE AS RELIGIÕES EM VISTA DE UM ECUMENISMO PLANETÁRIO}

Apesar de ainda haver dificuldades de compreensão mútua e de persistirem atitudes de intolerância por parte de grupos radicais, constata-se atualmente uma mesma vontade de diálogo por parte dos representantes das grandes religiões do mundo. O Concílio Vaticano II no n. 2 da declaração Nostra Aetate sobre as relações da Igreja católica com as religiões não cristãs, faz um julgamento positivo das mesmas. Afirma que as outras religiões vão "ao encontro das inquietações do coração humano", reconhecendo assim "todo um esforço, por parte das religiões em buscar a Deus, de diversos modos, através de símbolos, doutrinas e regras de vida e ritos sagrados." ${ }_{22}$ As outras tradições religiosas estão carregadas da presença do Deus vivo e verdadeiro que se comunica de forma plural e misteriosa.

Segundo Geffré, essa proximidade entre as religiões é coerente com a experiência histórica da humanidade nos últimos tempos. Geffré destaca que "a humanidade atingiu a sua idade planetária e, acima das divergências de raças, de culturas e de religiões, os homens têm consciência de habitar uma 'casa comum'." ${ }^{23}$ Em um contexto de globalização ou mundialização, devido ao estreitamente das distâncias, graças às tecnologias da informação, seria possível falar em um ecumenismo planetário ${ }^{24}$, onde o que une é mais importante do que aquilo que separa, e apesar de toda a humanidade estar sob o influxo da relatividade histórica, unanimemente e em conjunto, busca o Absoluto.

\footnotetext{
${ }^{19}$ GEFFRÉ, Claude. Crer e interpretar, p. 85.

${ }^{20}$ GEFFRÉ, Claude. Crer e interpretar, p. 101.

${ }^{21}$ Cf. GOMES, Tiago de Fraga. A teologia hermenêutica de Claude Geffré e a sua relevância para a teologia da revelação, p. 12-13.

${ }^{22}$ BOAVENTURA, Josuel dos Santos. O Deus único nas distintas formas de revelação, p. 387.

${ }^{23}$ GEFFRÉ, Claude. De Babel à Pentecostes, p. 14.

${ }^{24}$ Claude Geffré usa a expressão "ecumenismo planetário" na perspectiva de uma "mundialização" da consciência humana hodierna, a qual favorece não mais uma perspectiva "cristianizadora", mas sim, "cristificadora". Para Geffré, a humanidade atingiu uma "idade planetária", e por isso, precisa aprender a superar as divergências culturais e religiosas através do diálogo. A humanidade, vivendo em uma "casa comum", cada vez mais toma consciência de constituir uma "única família universal". Apesar da palavra "ecumenismo" ser usada comumente para indicar o diálogo entre os cristãos, Geffré a aplicada no âmbito mais amplo do diálogo entre as religiões, fazendo referência a "toda a terra habitada". Geffré quer frisar que, no que se refere aos valores éticos e soteriológicos emergentes das várias tradições religiosas, o que une é mais importante do que aquilo que separa.
} 
Geffré destaca que diante dos prodigiosos recursos técnicos e científicos, a humanidade dispõe, cada vez mais, de um poder potencialmente ameaçador para o futuro da espécie humana e para a preservação do planeta. "Em vez de buscar seu próprio interesse e de defender com fanatismo sua particularidade, as grandes religiões compreendem melhor a sua responsabilidade histórica a serviço do homem e da convivência entre os homens. Parece cada vez mais evidente que não haverá nem paz civil, nem paz mundial, sem paz entre as religiões." ${ }^{25}$ Nesse sentido, Hans Küng afirma que "não haverá paz entre as nações, se não existir paz entre as religiões. Não haverá paz entre as religiões, se não existir diálogo entre as religiões. Não haverá diálogo entre as religiões, se não existirem padrões éticos globais. Nosso planeta não irá sobreviver, se não houver um ethos global, uma ética para o mundo inteiro." ${ }^{26}$ As religiões têm um importante papel na construção da paz mundial.

Segundo Küng, o mundo inteiro precisa edificar um ethos global que favoreça uma convivência mais saudável entre as pessoas e o meio ambiente, pois "a sociedade só pode ser mantida unida por um ethos." ${ }^{27}$ Esse ethos encontrado nas diversas religiões precisa ser um ethos libertador, e não uma cadeia à qual fica-se atrelado; Um ethos vinculante, expressão de uma convicção básica para todas as pessoas, não servindo aos interesses egoístas de alguma classe; Um ethos tolerante, que não exclui e condena, mas que convida e anima. Isso acontece quando se encara as religiões pelo seu caráter libertador e humanizante, não atribuindo a elas um caráter repressivo ou dominante.

A declaração do ethos mundial, no parlamento das religiões, deve unir a humanidade e humanizá-la ainda mais. "A religião pode contribuir para dar aos homens de hoje sustento e apoio e manter unida a sociedade." ${ }^{28}$ A religião dá um amplo horizonte de interpretação e um sentido último para a vida do homem. Através de seus esforços, as religiões podem contribuir com "uma nova visão de conjunto e uma nova orientação espiritual básica que transmita identidade e segurança." ${ }^{29}$ Neste tempo turbulento e antagônico, as grandes religiões deverão encontrar um caminho "entre um modernismo sem fundamento e um fundamentalismo sem modernidade." ${ }_{30}$ Nos casos de conflito, se faz necessário buscar o caminho da tolerância e uma disposição para o diálogo, a fim de pacificar as relações.

Nos conflitos regionais, nacionais e internacionais, as religiões podem dar a sua contribuição de paz. "Em todas as grandes religiões existem motivações básicas não só para contribuir para a paz interior e individual como também para superar as agressões e a violência na sociedade." ${ }_{31}$ As religiões podem atenuar conflitos e evitar guerras. A paz entre as religiões se constrói sobre as bases da confiança, edificada arduamente, se emancipando de toda forma de preconceitos, seguindo o caminho da reconciliação, esclarecendo os mal-entendidos, elaborando as recordações traumáticas, dissolvendo as imagens estereotipadas do inimigo.

As religiões têm o dever de denunciar todo tipo de transgressão contra os direitos humanitários internacionais. Além de aderirem à Declaração Universal dos Direitos Humanos, as religiões devem fundamentá-los e concretizá-los, com impulsos éticos humanitários, de forma a "colaborar para a realização de um ethos universal da

\footnotetext{
${ }^{25}$ GEFFRÉ, Claude. De Babel à Pentecostes, p. 15.

${ }^{26} \mathrm{KÜNG}$, Hans. Religiões do mundo, p. 280.

${ }^{27} \mathrm{KÜNG}$, Hans. Uma ética global para a política e a economia mundiais, p. 250.

${ }^{28} \mathrm{KÜNG}$, Hans. Uma ética global para a política e a economia mundiais, p. 251.

${ }^{29} \mathrm{KÜNG}$, Hans. Uma ética global para a política e a economia mundiais, p. 259.

${ }^{30} \mathrm{KÜNG}$, Hans. Uma ética global para a política e a economia mundiais, p. 260.

${ }^{31} \mathrm{KÜNG}$, Hans. Uma ética global para a política e a economia mundiais, p. 260.
} 
humanidade" ${ }_{32}$, favorecendo a prática da tolerância e da solidariedade. Para isso, deve ser garantido e favorecido um livre exercício da religião sem discriminação e uma formação consistente para o diálogo em um mundo plural e multirreligioso. O destino de nosso planeta atinge todos os homens, seja qual forem as suas crenças.

Nessa mesma linha de pensamento, Geffré enfatiza que "na era planetária, a comunidade das nações exige uma ética global para todos os homens, acima da diversidade das religiões e das éticas particulares." "33 As religiões podem ter uma atuação importante na edificação de um ethos mundial para uma convivência saudável entre as pessoas. A Declaração Universal dos Direitos Humanos é expressão dessa consciência humana universal. Em função dessa nova experiência histórica, todas as religiões devem estar dispostas a reinterpretar os seus textos fundadores em vista do diálogo e da busca de caminhos comuns. A crueldade das experiências do século XX basta para convencer toda a humanidade da fragilidade da consciência humana entregue a si mesma.

Geffré enumera algumas condições para que haja um verdadeiro diálogo entre as pessoas das diversas religiões. A primeira condição é o respeito ao outro na sua diferença e identidade própria, manifestando interesse por suas convicções e ultrapassando os preconceitos espontâneos, pois "cada religião é uma totalidade que carrega consigo toda a sua história, e um elemento particular só pode ser compreendido em referência a essa totalidade." ${ }_{34} \mathrm{O}$ problema é que muitas vezes as pessoas têm dificuldades em assumir convicções que lhes são cultural e religiosamente estranhas. ${ }^{35}$ É preciso cultivar o senso de uma hermenêutica da diferença ao estilo bíblico que prescinda de uma lógica da assimilação. Seguindo o pensamento de David Tracy em sua obra The analogical imagination $^{36}$, é preciso cultivar uma imaginação analógica, a qual desvela uma semelhança na diferença, mantendo a diferença, de modo que se possa escapar do equívoco sem cair no unívoco.

A segunda condição para o diálogo é a fidelidade à própria identidade. "É uma ilusão pensar que, para facilitar o diálogo religioso, é preciso pôr a sua fé religiosa entre parênteses ou suspendê-la provisoriamente" ${ }^{37}$, isso seria um falso cálculo. Segundo Geffré, não existe diálogo quando a pessoa não está localizada em lugar nenhum, e ainda assim, pretende, sob o pretexto de abertura e de universalidade, aceder a uma espécie de cidadania mundial. ${ }^{38}$ Valer-se de uma religião mundial é perder a qualidade de interlocutor. É a partir de um engajamento religioso pessoal que cada interlocutor deve respeitar as condições do outro, mesmo naquelas divergências que são inegociáveis, pois nem todas as verdades de ordem religiosa são necessariamente complementares, já que há lógicas que são inconciliáveis. Um diálogo existencial sincero visa conduzir a uma melhor inteligência da própria identidade e à celebração de uma verdade mais ampla.

Como terceira condição, Geffré diz que no diálogo é preciso reconhecer certa igualdade entre os parceiros, pois "quem diz diálogo diz abertura" ${ }_{39}$, e procurar encontrar uma base ou criteriologia comum sobre a qual se possam estabelecer os fundamentos de um acordo, edificando a unidade na diversidade. Esse critério pode ser a consciência do humano autêntico como fruto de um melhor conhecimento dos direitos humanos e

\footnotetext{
${ }^{32} \mathrm{KÜNG}$, Hans. Uma ética global para a política e a economia mundiais, p. 265.

${ }^{33}$ GEFFRÉ, Claude. De Babel à Pentecostes, p. 15.

${ }^{34}$ GEFFRÉ, Claude. De Babel à Pentecostes, p. 16.

${ }^{35} \mathrm{Cf}$. GEFFRÉ, Claude. Crer e interpretar, p. 144.

${ }^{36}$ Cf. TRACY, David. The analogical imagination. New York: Crossroad, 1981.

${ }^{37}$ GEFFRÉ, Claude. De Babel à Pentecostes, p. 16.

${ }^{38} \mathrm{Cf}$. GEFFRÉ, Claude. Crer e interpretar, p. 145.

${ }^{39}$ GEFFRÉ, Claude. Crer e interpretar, p. 146.
} 
das legítimas aspirações da consciência humana universal ${ }^{40}$, a descentralização de si em benefício de uma Realidade última, a fé fundamental das religiões ou mesmo o homo religiosus. O perigo dessa atitude é postular uma essência do sagrado ou da religião, quando de fato só é possível conhecer as suas realizações históricas. ${ }^{41}$ Por isso, essas condições são apenas proposições ou pistas balizadoras de um diálogo autêntico, o qual nunca deixa de ser complexo, e até muitas vezes paradoxal. No entanto, o resultado do diálogo "é descobrir que há um além do diálogo, a saber, a transformação de cada um dos interlocutores." ${ }_{42}$ Cada um é mudado na maneira de apropriar-se da própria fé quando é confrontado com a verdade do outro. Isso não significa a perda ou a perversão da fé pessoal, mas aponta para uma relativização da maneira como se pretende possuir a verdade, permitindo-se reinterpretar as próprias tradições. Verdades diferentes não são necessariamente contraditórias, mas podem ampliar a visão parcial de cada interlocutor.

Na visão de Geffré, é preciso reconhecer que "a própria revelação cristã é inadequada em relação à plenitude de verdade que está em Deus, assim como a humanidade de Jesus é inadequada em relação à riqueza do Verbo de Deus. Ela é ainda uma tradução." ${ }^{43}$ Fazendo uma diferenciação entre o valor qualitativo e o conteúdo quantitativo da revelação cristã, se poderia afirma que este último está constantemente suscetível a novas explicitações. Qualitativamente, a revelação em Cristo é incomparável. Porém, do ponto de vista de sua objetivação e inteligibilidade, se trata de uma tradução repleta de limitações, pois está sob o signo da relatividade e da contingência. Uma consciência saudável da relatividade inerente ao cristianismo histórico impede de cair tanto no relativismo quanto no absolutismo. Dentro do âmbito da imanência histórica, o cristianismo é uma realidade relacional, cuja verdade testemunhada não é nem inclusiva e nem exclusiva de toda a verdade, mas relativa ao que há de verdadeiro nas outras religiões, o que deve levar a uma prática cordial e empática da alteridade.

\section{CONCLUSÃO}

Entre os diversos temas em pauta na atualidade, "o pluralismo, é objeto crescente de reflexão e análise, em diversas áreas do conhecimento humano." "Vários autores de renome se ocupam do tema em âmbito teológico, percebendo que este é um assunto de fundamental importância. Geffré é um desses pensadores que refletem sobre o pluralismo religioso de maneira original e instigante ${ }^{45}$, desenvolvendo uma teologia que favorece o encontro entre as religiões, numa abertura dialógica e relacional. Entre outros autores que possuem afinidade com o tema, Christian Duquoc alerta para a necessidade da teologia se abrir ao diálogo "diante de uma disseminação legítima das religiões: elas são caminhos autênticos na busca do divino." ${ }^{46}$ Nessa mesma linha de pensamento, Andrés Torres Queiruga salienta que "as religiões, cada uma delas, são totalidades complexas de resposta ao divino" 47 , e, por isso mesmo, são uma abertura à transcendência que humaniza. A questão do pluralismo religioso é, nesse sentido, uma problemática que favorece muitas reflexões na atualidade.

\footnotetext{
${ }^{40}$ Cf. GEFFRÉ, Claude. Crer e interpretar, p. 152.

${ }^{41}$ Cf. GEFFRÉ, Claude. De Babel à Pentecostes, p. 18.

${ }^{42}$ GEFFRÉ, Claude. Crer e interpretar, p. 146.

${ }^{43}$ GEFFRÉ, Claude. Crer e interpretar, p. 147.

${ }^{44}$ KLERING, José Romaldo. Pluralismo, re-significação e diálogo, p. 169.

${ }^{45} \mathrm{Cf}$. TEIXEIRA, Faustino. A teologia do pluralismo religioso em Claude Geffré, p. 46.

${ }^{46}$ DUQUOC, Christian. A teologia no exílio, p. 29.

${ }^{47}$ TORRES QUEIRUGA, Andrés. O diálogo das religiões, p. 16.
} 
O pluralismo está presente no interior das religiões e do próprio cristianismo. É possível perceber isso nas diferentes interpretações das diversas denominações cristãs, e mesmo especificamente dentro do catolicismo, nas suas variadas linhas de espiritualidade e de pastoral. O paradigma pluralista atravessa o cristianismo em vários níveis, desde o ad intra ao ad extra, fazendo-o se re-situar em sua própria identidade e cosmovisão. Por isso, é importante reconhecer o outro, estar aberto ao diálogo, superando a lógica da assimilação no sentido grego e hegeliano, porém, sem perder os referenciais identitários pessoais e comunitários, buscando, no entanto, caminhos comuns, no aprendizado contínuo da convivência democrática entre as pessoas dentro da esfera pública. Em um contexto plural e globalizado, emerge a necessidade de reconhecimento das diferenças irredutíveis e da busca de consensos democráticos bem fundamentados. As religiões têm uma importante contribuição a prestar para a sociedade na construção da paz desde que compreendam o seu potencial de humanização.

Apesar de uma crescente pentecostalização da fé dentro da Igreja católica e de várias denominações cristãs, com seus excessos pastorais, seus fanatismos fundamentalistas, em uma negação obstinada do senso crítico, em nome de uma fidelidade radical à vontade de Deus, na teologia contemporânea, há a tendência equilibrada em considerar a veracidade da pluralidade religiosa. São muitas as formas religiosas, sendo que todas elas trazem, de modos diversos, elementos de contato com o divino que edifica um humano autêntico. O Papa Francisco fala na Laudato Si' n. 201 que "a maior parte dos habitantes do planeta declara-se crente, e isto deveria levar as religiões a estabelecer diálogo entre si, visando o cuidado da natureza, a defesa dos pobres, a construção de uma trama de respeito e fraternidade." A busca de um ecumenismo teológico a nível planetário é uma urgência ambiental e humanitária no contexto global hodierno e uma tarefa para os cristãos e para os membros das diversas religiões do mundo.

\section{REFERÊNCIAS}

BÍBLIA. Português. A Bíblia de Jerusalém. Nova edição rev. e ampl. São Paulo: Paulus, 2002.

BOAVENTURA, Josuel dos Santos. O Deus único nas distintas formas de revelação. Teocomunicação, Porto Alegre, v. 36, n. 152, p. 383-421, jun. 2006.

BOFF, Leonardo. Fundamentalismo: a globalização e o futuro da humanidade. Rio de Janeiro: Sextante, 2002.

CONCÍlIO ECUMÊNICO VATICANO II, 1962-1965, Cidade do Vaticano. Nostra Aetate. In: COSTA, Lourenço (Org. Geral). Documentos do Concílio Ecumênico Vaticano II (1962-1965). 4. ed. Trad. Tipografia Poliglota Vaticana. São Paulo: Paulus, 2007. (Documentos da Igreja), p. 339-346.

Unitatis Redintegratio. In: COSTA, Lourenço (Org. Geral). Documentos do Concílio Ecumênico Vaticano II (1962-1965). 4. ed. Trad. Tipografia Poliglota Vaticana. São Paulo: Paulus, 2007. (Documentos da Igreja), p. 215-240.

DUPUIS, Jacques. Rumo a uma teologia cristã do pluralismo religioso. Trad. Márcia de Almeida; Euclides Martins Balancin. São Paulo: Paulinas, 1999.

DUQUOC, Christian. A teologia no exílio: o desafio da sobrevivência da teologia na cultura contemporânea. Trad. Gentil Adelino Titton. Petrópolis: Vozes, 2006.

FRANCISCO, Papa. Carta Encíclica Laudato Si': sobre o cuidado da casa comum. São Paulo: Paulus; Loyola, 2015.

Exortação Apostólica Evangelii Gaudium: sobre o anúncio do Evangelho no mundo atual. São Paulo: Paulinas, 2013.

GEFFRÉ, Claude. Como fazer teologia hoje: hermenêutica teológica. Trad. Benôni Lemos. São Paulo: Paulinas, 1989. 
Crer e interpretar: a virada hermenêutica da teologia. Trad. Lúcia M. Endlich Orth. Petrópolis: Vozes, 2004.

. De Babel à Pentecostes: ensaios de teologia inter-religiosa. Trad. Margarida Maria Cichelli Oliva. São Paulo: Paulus, 2013.

GOMES, Tiago de Fraga. A teologia hermenêutica de Claude Geffré e a sua relevância para a teologia da revelação. 2015. 140 f. Dissertação (Mestrado em Teologia) - Faculdade de Teologia, Pontifícia Universidade Católica do Rio Grande do Sul, Porto Alegre, 2015.

. Hermenêutica teológica e teologia da revelação em Claude Geffré. In: SUSIN, Luiz Carlos; RODRIGUES, Jéferson Ferreira (Orgs.). Fazer teológico. Porto Alegre: Editora Fi, 2015.

HAMMES, Érico João. Hermenêutica e teologia: interpretar é preciso. In: PICH, Roberto Hofmeister; ZILlES, Urbano (Orgs.). Filosofia, religião e ciência. Porto Alegre: Edições Est, 2008.

KLERING, José Romaldo. Pluralismo, re-significação e diálogo. Teocomunicação, Porto Alegre, v. 34, n. 143, p. 169-182, mar. 2004.

KÜNG, Hans. Uma ética global para a política e a economia mundiais. Trad. Carlos Almeida Pereira. Petrópolis: Vozes, 1999. Verus, 2004.

Religiões do mundo: em busca dos pontos comuns. Trad. Carlos Almeida Pereira. Campinas:

LACOSTE, Jean-Yves. Dicionário crítico de teologia. Trad. Paulo Meneses; Maria Stela Gonçalves; Marcos Bagno; Nicolás Nyimi Campanário; Marcelo Perini. São Paulo: Paulinas; Loyola, 2004.

TORRES QUEIRUGA, Andrés. O diálogo das religiões. São Paulo: Paulus, 1997.

SILVA, Cássio Murilo Dias da. Crítica bíblica: um remédio contra o fundamentalismo. In: MINCATO, Ramiro (Org.). Bíblia: ciência, fundamentalismo e exorcismo. Porto Alegre: Edições Est, 2007.

TEIXEIRA, Faustino. A teologia do pluralismo religioso em Claude Geffré. Numen, Juiz de Fora, v. 1, n. 1, p. 45-83, jan./jul. 1998.

. Teologia das religiões: uma visão panorâmica. São Paulo: Paulinas, 1995.

TRACY, David. The analogical imagination. New York: Crossroad, 1981.

Recebido em: 29/09/2017

Aprovado em: 20/11/2017

\section{Correspondência para:}

Tiago de Fraga Gomes

Rua do Comércio, 542 - Barra do Ouro

95532-000 Maquiné, RS, Brasil 